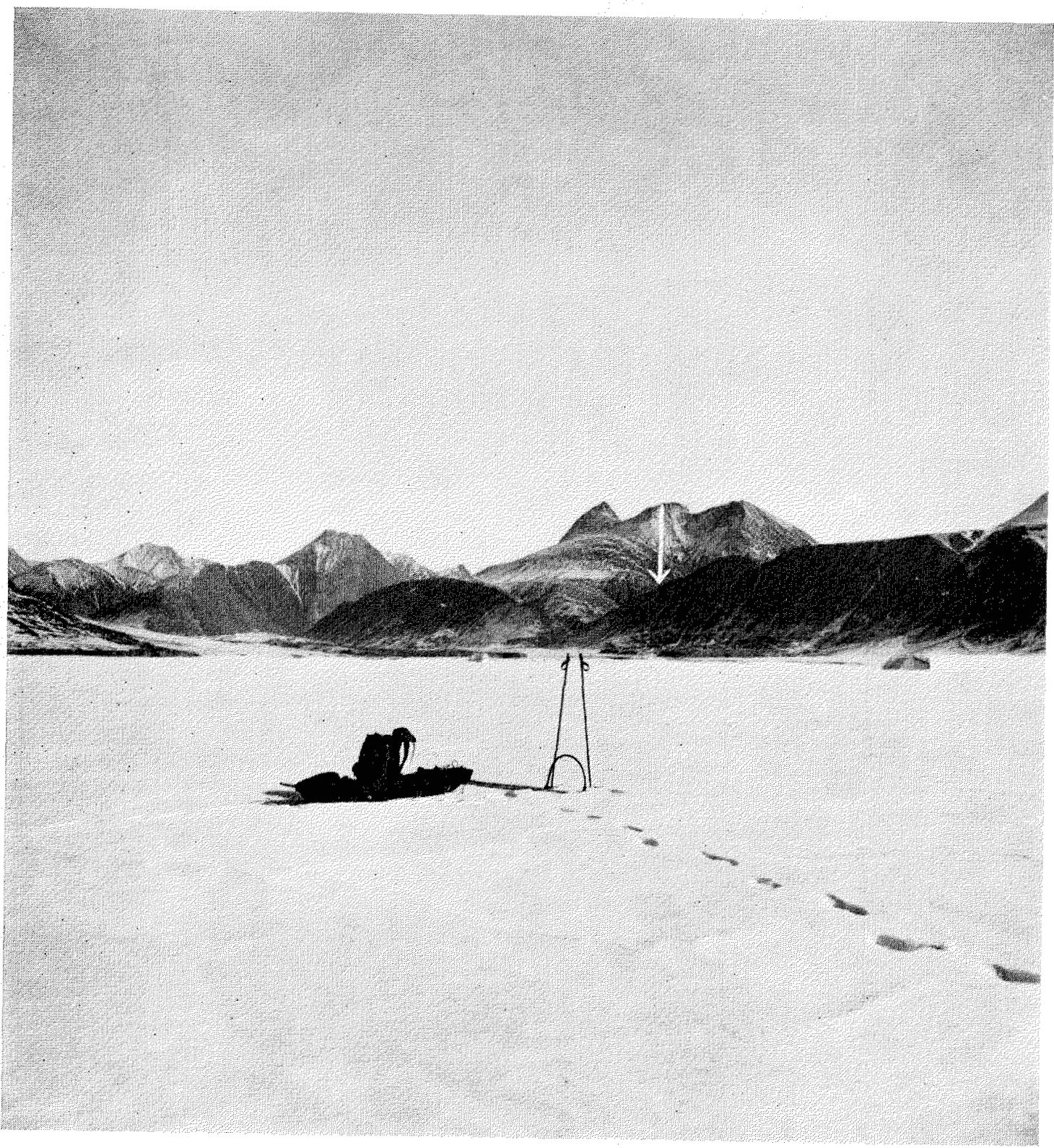

Fig. 1. Looking southeast across Caledonian Bay, east coast of Canyon Fiord. The peaks in the background consist of dark limestone, presumably corresponding to the Offley Island formation of Middle Silurian (Late Llandovery; Clinton) age. To the left of the peak in the centre may be seen a gap in the ridge. This gap indicates the position of steeply dipping graptolite shales (visible in Fig. 6 as a dark band) which may belong to the Cape Tyson formation of Late Silurian (Tarannon-Wenlock) age. The low hills near the coast consist of sandstones and shales, which provisionally are referred to the Polaris Harbour formation of doubtful Late Silurian (Ludlow) age. The "shoulder" or plateau remnant between the high peaks and the coast is clearly seen. The arrow indicates the locality shown in Fig. 7. May 1952. 


\title{
GEOLOGICAL INVESTIGATIONS IN ELLESMERE ISLAND， 1952
}

\author{
J. C. Troelsen*
}

D R. LAUGE Koch's ideas on the age of the folded mountain system in north Greenland and Ellesmere Island have for the last thirty years been a storm centre in Scandinavian geology. It has been maintained by several geologists that Koch's theory of a Caledonian age of the folding was not supported by acceptable evidence, and as late as 1950 Hans Frebold (1951, p. 42) stated that: "Das Alter der Nordgrönland-Grinnell-Land-Faltenzone ist noch ungeklärt und neuerdings bekanntgewordene Tatsachen sprechen für das Vorliegen jüngerer Faltungen in diesem Raume" ("The age of the north Greenland-Grinnell Land zone of folding is not yet known, and recently published evidence suggests the presence of younger foldings within this area").

On the Danish Thule-Ellesmere Land Expedition in the spring of 1940 I attempted unsuccessfully to solve the problem of the age of the mountain system in Ellesmere Island, though clear evidence was found of a gentle postTriassic folding. Circumstantial evidence derived from the literature and from my field observations suggested, however, that the main folding of the mountain system took place some time between the Silurian and the Middle Carboniferous periods, possibly in Late Silurian and/or Middle to Late Devonian time (Troelsen, 1950a).

Later, as a member of the Danish Pearyland Expedition, I was able to prove that a folding had taken place between Middle Ordovician (Silurian fossils were found in the unfolded sequence but not within the belt of folding) and Late Carboniferous times in the north Greenland end of the mountain system (Troelsen, 1950b). In Peary Land there is thus a considerable time gap between the folded and the overlying unfolded rocks and, as the sequence of geological events has not necessarily been the same throughout the north Greenland-Ellesmere Island mountain system, further research in Ellesmere Island was needed.

In 1940 I formed the impression that the key to the problem should be sought somewhere near Canyon Fiord, west Ellesmere Island, but I was unable to spend much time looking for it. When I heard that a weather station had been built in 1947 at Slidre Fiord, not far from Canyon Fiord, I decided to make another attempt at the mountain folding in Ellesmere Island, but it was not until March 1952 that I was ready to leave for the Arctic.

The 1952 expedition was made possible in part by a grant from the Arctic Institute of North America, with funds provided by the U.S. Government. When it became apparent that the budget as originally planned was insufficient, the University of Copenhagen and the Danish Rask- $\varnothing$ rsted Foundation made

${ }^{*}$ Curator, Mineralogisk-geologisk Institur, University of Copenhagen. 


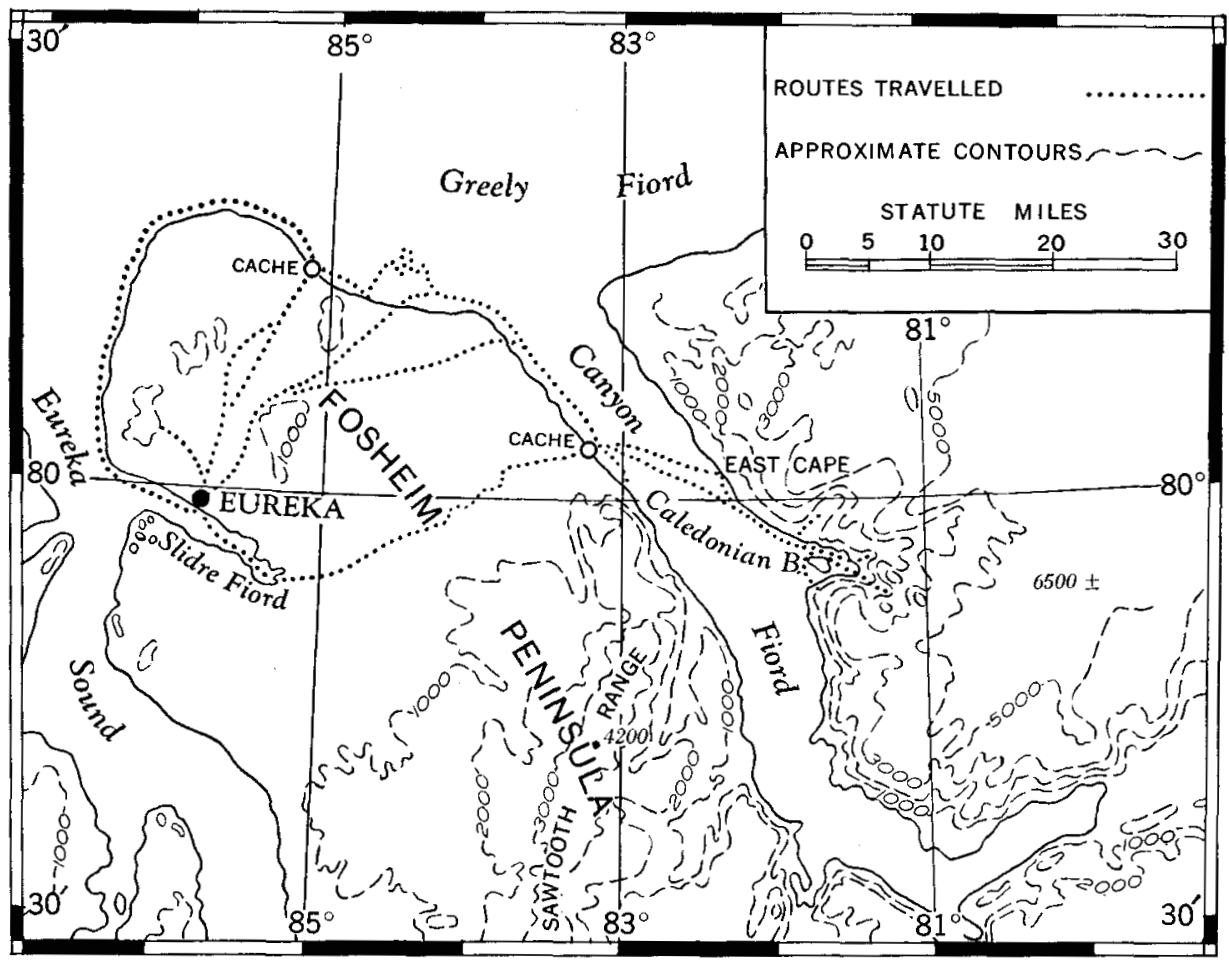

Fig. 2. Sketch-map of west central Ellesmere Island, based on World Aeronautical Chart No. 20, published June 1951.

additional grants. The Defence Research Board in Ottawa lent a set of R.C.A.F. photographs of the Canyon Fiord region and, together with the Arctic Institute, assisted me in planning details of the expedition. Permission to use the Eureka weather station as a base was granted by the Controller of the Meteorological Division, Canadian Department of Transport. Transportation from Montreal to the Arctic and back was provided by the R.C.A.F., the U.S.A.F., and the U.S. Navy. I am indebted to all these institutions and agencies and to many individuals for help and advice.

\section{Field work}

Previous expeditions to the Canyon Fiord region: the Second Norwegian Polar Expedition in the Fram, 1898-1902; the Macmillan Crocker Land Expedition, 1913-7; and the Danish Thule-Ellesmere Land Expedition, 1939-41, had travelled with sledges pulled by large dog teams. Because of the expense and difficulties involved in securing and transporting a complete dog team and their food to Ellesmere Island, I had planned to use a light Swedish pulka drawn by one or two dogs. Unfortunately, on my arrival in northwest Greenland in April 1952 I found that an outbreak of dog disease made it impossible to obtain any dogs there, and an offer to lend me some from the Eureka weather station had to be declined as they were not trained for 


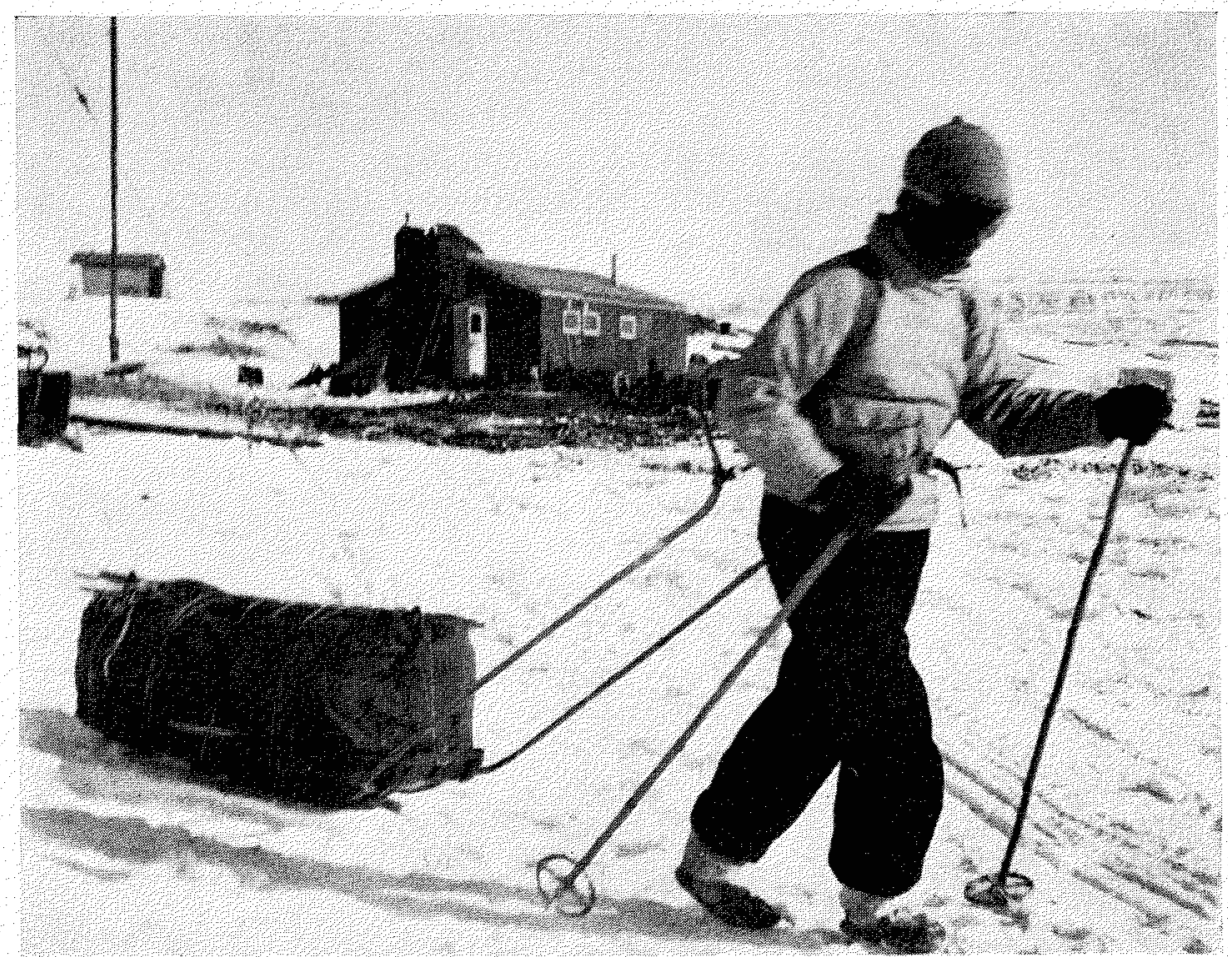

Fig. 3. The second start from Eureka weather station. May 1952.

sledging. For reasons beyond the control of the weather station no mechanical transportation was available at the time. As it was now too late to abandon or postpone the expedition, I therefore decided to pull the pulka myself.

On April $19 \mathrm{I}$ arrived by air at Eureka weather station, on the north coast of Slidre Fiord, and set out the following day for Canyon Fiord. The route lay through Slidre Fiord and across the low plain northwest of Sawtooth Range. $^{1}$ As the load was very heavy, relaying had to be resorted to, and it soon became apparent that the most advantageous course would be to cache as much food and kerosene as possible on the west coast of Canyon Fiord and then to return to the weather station for additional supplies. On May 1 I was back at the base, and left again for Canyon Fiord on May 4. As the going on the plain and along the river beds was already deteriorating because of evaporation of the snow on the gravel banks, I decided to travel on the sea ice north around Fosheim Peninsula. It took five days to reach the cache in Canyon Fiord and another two days to Caledonian $\mathrm{Bay}^{2}$ on the east coast of the fiord.

A careful study of stereoscopic pairs of air photographs had indicated that two areas were of special interest: at Caledonian Bay and to the southwest of

1This is the name in local use. It has not as yet been adopted by the Canadian Board on Geographical Names.

2This name has not as yet been adopted by the Canadian Board on Geographical Names. 
the head of Canyon Fiord. ${ }^{1}$ As it turned out, it was most fortunate that the first area held the answers to most of the problems with which I was concerned.

Special permission had been obtained to shoot a small number of Arctic hares, ${ }^{2}$ as I had been asked to make a collection for a Danish zoologist. Naturally I wanted to kill the hares at a time and place where their meat would be of most use, so I had planned to take them on the east coast of Canyon Fiord. Although former travellers had found Canyon Fiord to be teeming with Arctic hares, I did not see a single one, and during my stay here I subsisted on hardtack and dried codfish, supplemented by some military K-rations. By strict rationing the stay in Caledonian Bay was extended to ten days, during which time the more important problems concerning the mountain folding were solved. The plans for an examination of the southern part of Canyon Fiord could thus be abandoned without seriously affecting the scientific program.

The last bit of food was eaten before I revisited my cache (or what remained of it) on the west coast of the fiord. Within half an hour, five hares had been killed in a valley nearby and many more were seen. After collecting some Mesozoic and Permian fossils at a point a few miles south of the cache I started back towards the weather station with a full load of fossils and rock samples.

By the time I reached the mouth of Canyon Fiord, the only food left was some carcasses of Arctic hares. As it turned out to be a rather trying experience to do hard work on a straight diet of hare meat, I temporarily abandoned camp and sledge and walked overland to the weather station. The 33-mile trip seemed rather a long one, but on the morning of May 27 I reached my goal.

After a few days spent in resting and eating, I carried a food depot to the north coast of Fosheim Peninsula. Later, on June 7, with my rucksack once more filled with food, I walked overland to the campsite at the mouth of Canyon Fiord. The rivers in northeastern Fosheim Peninsula were now in flood. Some of the largest and swiftest streams had a coating of slippery ice on the bottom, while others flowed in beds of deep slush. In all, no less than thirty-six hours were spent in covering the distance of 35 miles.

On the sea ice the snow had now given way to shallow pools of meltwater, and leads were opening everywhere. The largest leads were at the mouths of the main rivers and could only be crossed after they had been followed seawards for several miles. In a number of places patches of hummocky ice, probably old floe ice, cut by a maze of deep channels and ponds, had to be crossed.

Gradually the bottom of the pulka wore out and, when the inside crosspieces began to drag on the ice, progress became nearly impossible. (In fairness to the manufacturer it should be mentioned that by far the greater part of this

${ }^{1} \mathrm{~A}$ plotting grid engraved on plexiglass was used for making rough estimates of distances and directions. The grid did not make any allowance for the variation of the angle of depression of individual photographs and, in this region, the relief of the mountainous areas was much too great for the proper application of the perspective grid method, but the grid was nevertheless useful for rapid work.

2Ellesmere Island is a game preserve. 


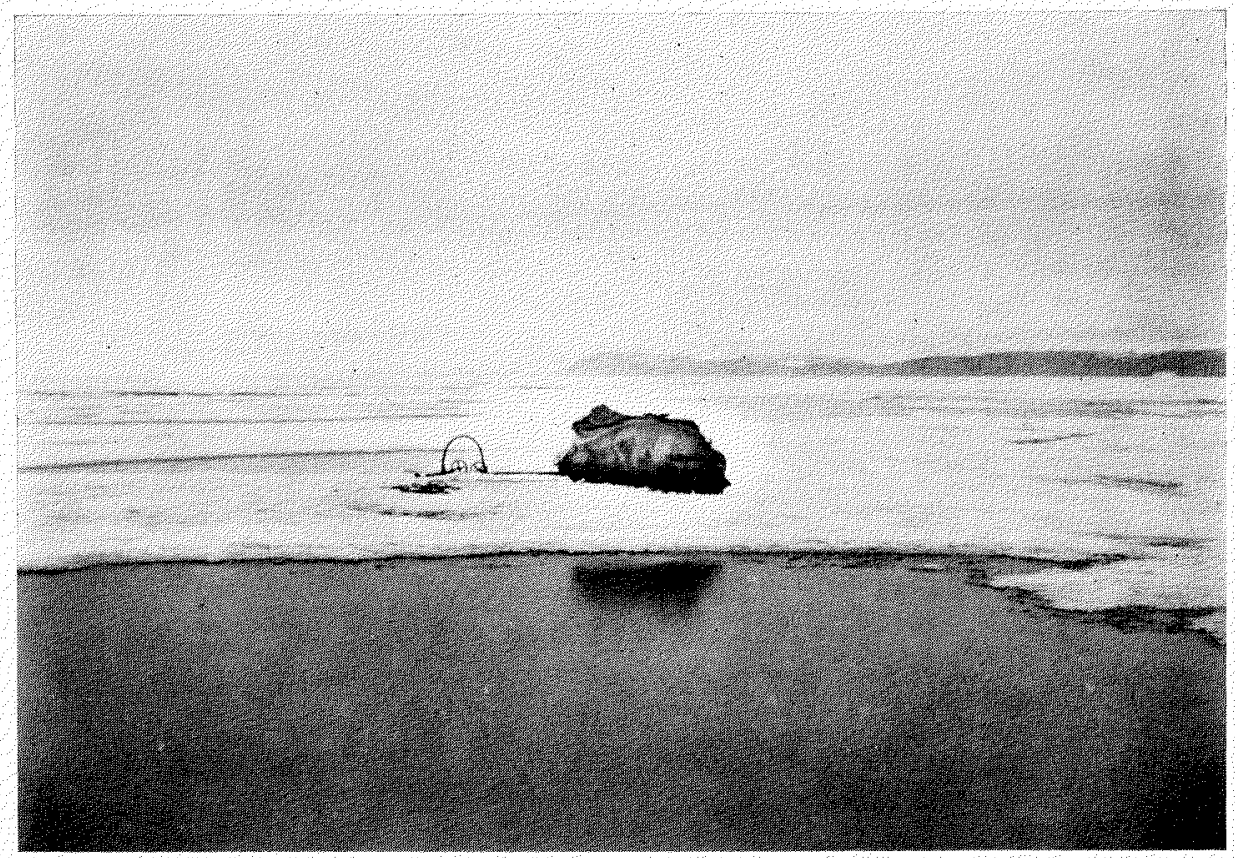

Fig. 4. The sea ice to the north of Fosheim Peninsula in mid June. The north coast of Greely Fiord may be seen in the background.

Fig. 5.

The bottom of the pulka after

some

350 miles of

sledging.

June 1952.

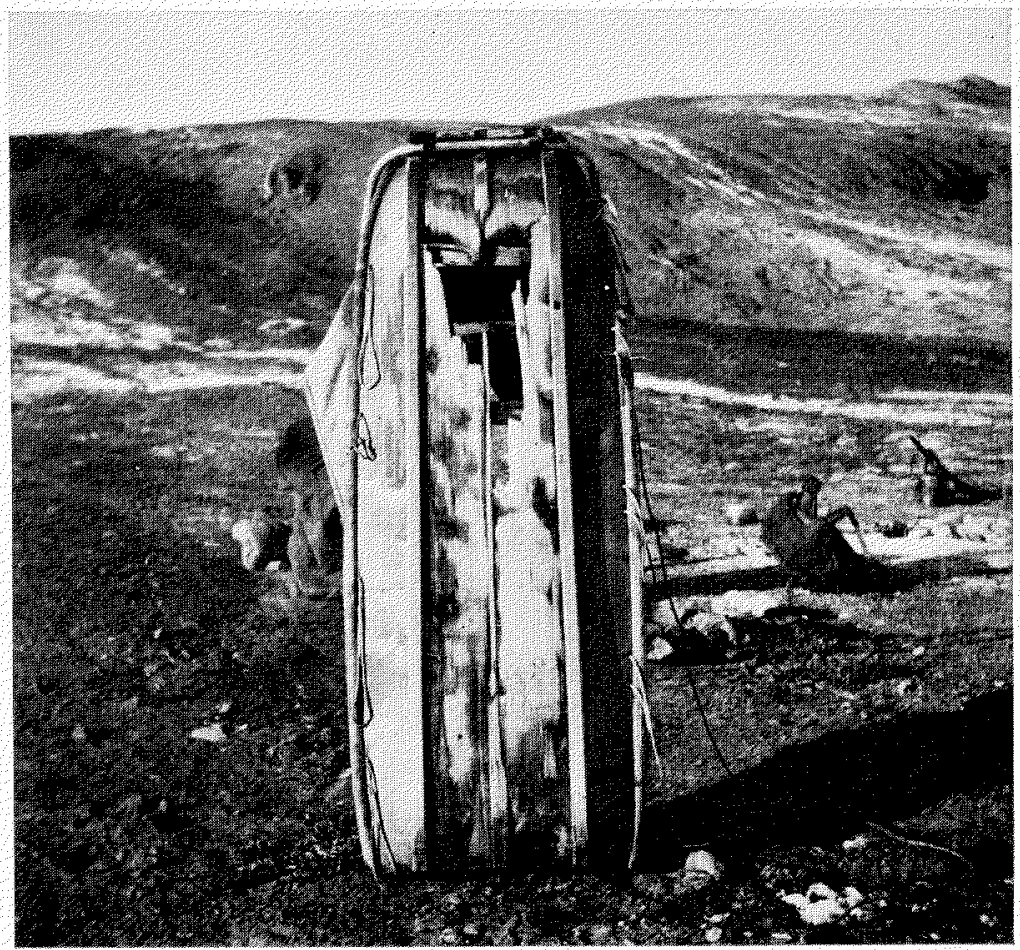




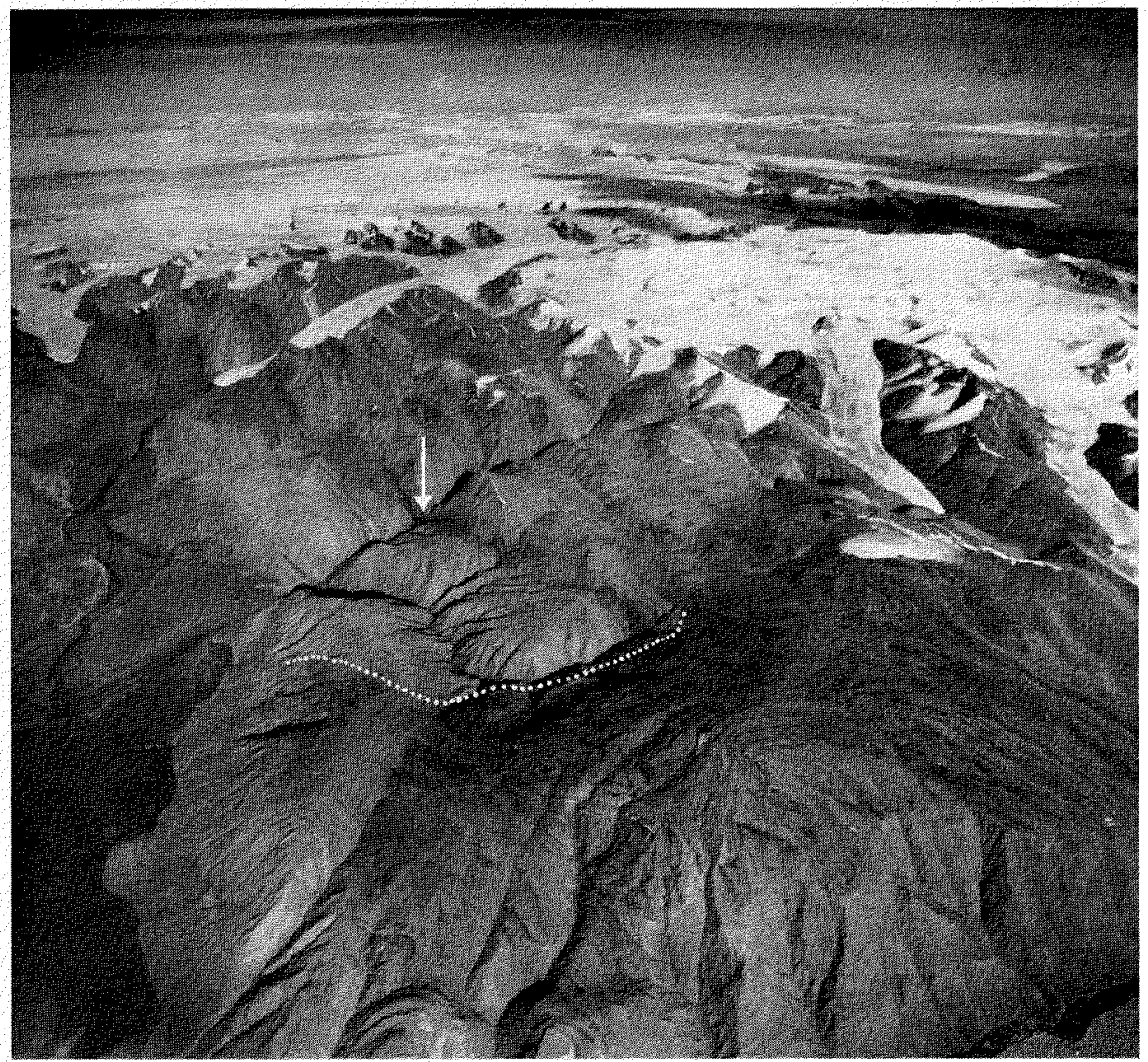

Photo: R.C.A.F

Fig. 6. Looking east across Caledonian Bay. The dotted line indicates the contact between the Middle Carboniferous in the foreground and the strongly folded Lower Paleozoic sediments. The Carboniferous rocks were disturbed by warping and weak folding in Late Mesozoic-Cenozoic time. The arrow indicates the locality shown in Fig. 7.

wear occurred during the last few days of travelling across rough, melting ice). Some 17 miles from the weather station I abandoned the sledge on the shore and walked back to the station, carrying only my notebooks, maps, and instruments. I was touched to find that the personnel at the base had left a food cache at the mouth of Slidre Fiord to lighten my return journey.

As my watch had stopped during a period of foggy and cloudy weather, I had lost track of time. On my return to the weather station I learned that I was two days overdue (it was now June 18) and that the R.C.A.F. had been requested to search for me. Fortunately we succeeded in contacting them before the search plane had taken off.

Towards the end of June the shore lead had opened so much that a canoe could reach the abandoned sledge. A wolf had torn a hole in the sledge cover and stolen the hare skulls, but all the other collections were brought back safely. 


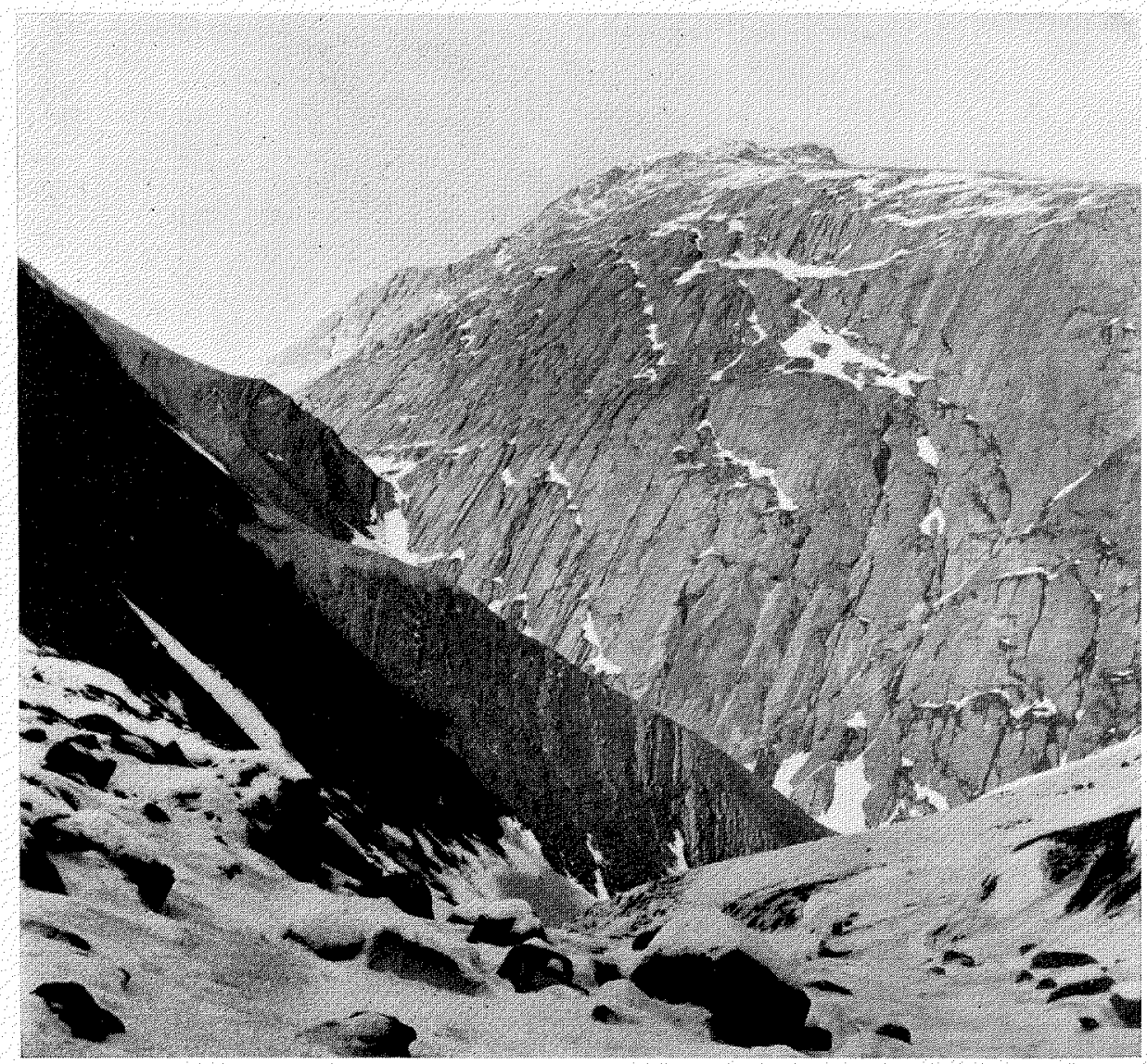

Fig. 7. In a valley running northwest to the head of Caledonian Bay. The steeply dipping graptolite shales in the foreground are believed to correspond to the Late Silurian (Tarannon-Wenlock) Cape Tyson formation. In the background there is a dip slope developed on the upper surface of a dark limestone, which presumably corresponds to the Middle Silurian (Late Llandovery; Clinton) Offley Island formation. May 1952.

The remainder of the summer was spent in the vicinity of the weather station, making geological, botanical, and zoological collections. On August 18 I left Eureka weather station.

\section{Geology}

\section{Scientific results}

The ridge immediately north of Caledonian Bay, on the east coast of Canyon Fiord, mainly consists of a large anticline, which is built up of unfossiliferous sandstones, slates, limestones, chert beds, and chert conglomerates. The age of this sequence is unknown but may conceivably be Late Precambrian.

South of Caledonian Bay there is a large syncline (Figs. 1 and 6), which seems to be separated from the large anticline by a major fault. The syncline is composed of fossiliferous limestones, shales, and sandstones (Fig. 7). On 
the basis of lithological similarities and field identifications of fossils these beds have tentatively been assigned to the following formations, which are known from the unfolded sequence in north Greenland (Koch, 1929, pp. 238-42):

The Offley Island formation, of Middle Silurian (Late Llandovery; Clinton) age.

The Cape Tyson formation, of Late Silurian (Tarannon-Wenlock) age.

The Polaris Harbour formation, of doubtful Late Silurian (Ludlow) age. Until the study of the collections has been completed this comparison cannot profitably be carried any further, but it is certain that Silurian fossils occur in the syncline.

Although the folding of the Lower Paleozoic strata around Caledonian Bay has been rather intensive, no metamorphic rocks above the rank of slate have been found. Neither were any intrusive rocks observed. ${ }^{1}$ Similar conditions are known from northern Ellesmere Island (Troelsen, 1950a). There are therefore good reasons for classifying those parts of the folded mountains which have been examined as belonging to a miogeosyncline.

Around Caledonian Bay, Middle Carboniferous sandstones and limestones (with Fusulina and Fusulinella) are found resting upon (1) the folded unfossiliferous sedimentary strata north of the bay and (2) the folded Silurian sedimentary strata south of the bay (Figs. 1 and 8). The low island in the bay also consists of Carboniferous rocks. It was definitely proved that the contact between the Carboniferous and the older rocks is an irregular erosion surface overlain by a coarse conglomerate of water-worn pebbles.

1River gravels, moraines, and the Carboniferous basal conglomerate were also searched unsuccessfully for intrusives and highly metamorphosed rocks.

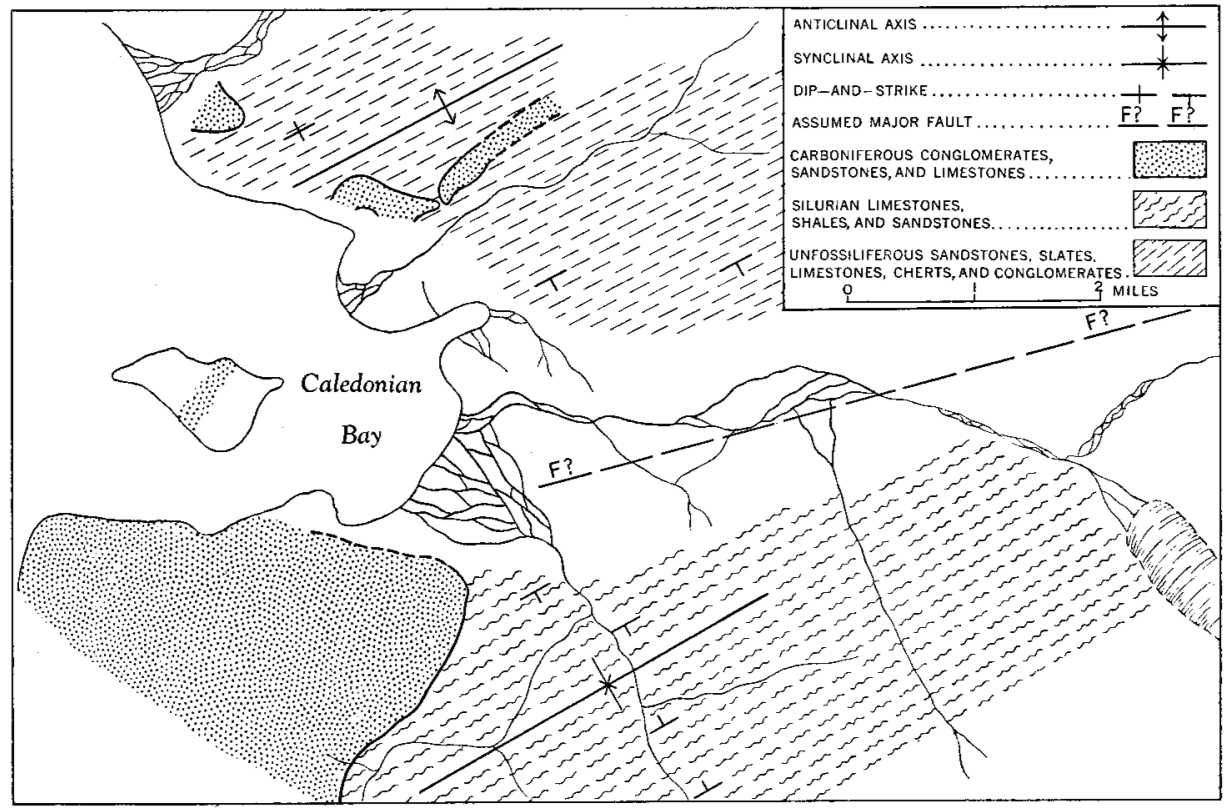

Fig. 8. Geological sketch-map of Caledonian Bay. 


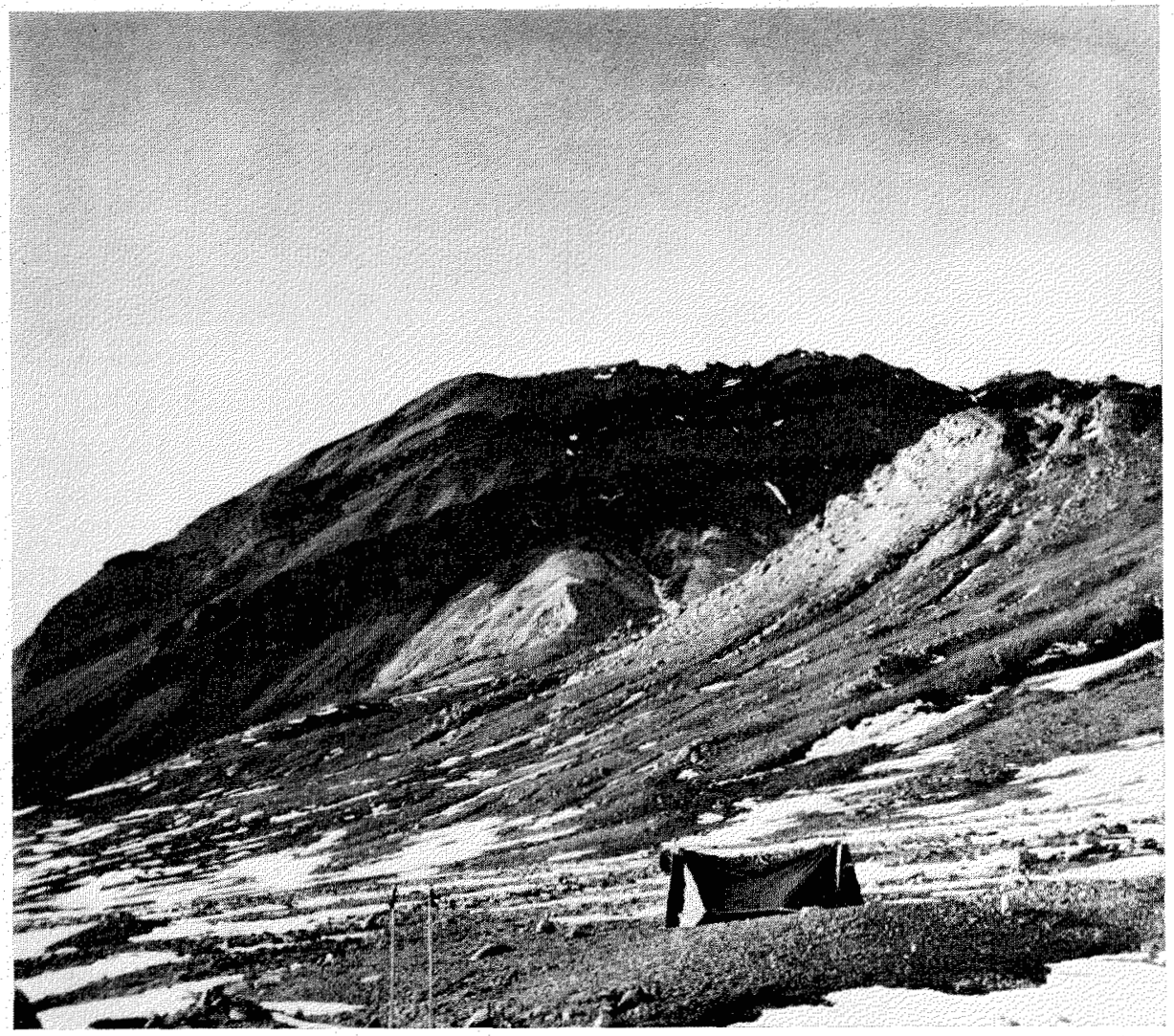

Fig. 9. Looking north towards East Cape. Dark Permian limestones (dipping away from the observer) have been thrust on top of light-coloured sandstones of Permian or Carboniferous age (dipping towards the observer). The thrusting is an effect of the Late Mesozoic or Cenozoic orogeny. May 1952.

The Carboniferous rocks truncate the older, folded rocks. At one place north of Caledonian Bay, a small erosional valley that parallels the trend of the old anticline was found to have been filled with Carboniferous sandstone. I got the impression that by Carboniferous time a bay already existed in the Caledonian Bay area (in this case, the assumed major fault was probably formed before Carboniferous time). The bay was filled with Carboniferous sediments, and later the whole structure was slightly warped. In comparatively recent geological time erosional forces have re-excavated the bay to form what is now Caledonian Bay and the large valley behind it. North of Caledonian Bay the erosion has been so thorough that only small patches of the Carboniferous strata have been left here and there on the hill sides.

For the first time in Ellesmere Island we thus have positive, irrefutable evidence of a post-Silurian (or possibly Late Silurian) but pre-Middle Carboniferous folding. This, together with what is now known about Peary Land (Troelsen, 1950b), proves the essential correctness of Lauge Koch's theory as to the age of the folding. 


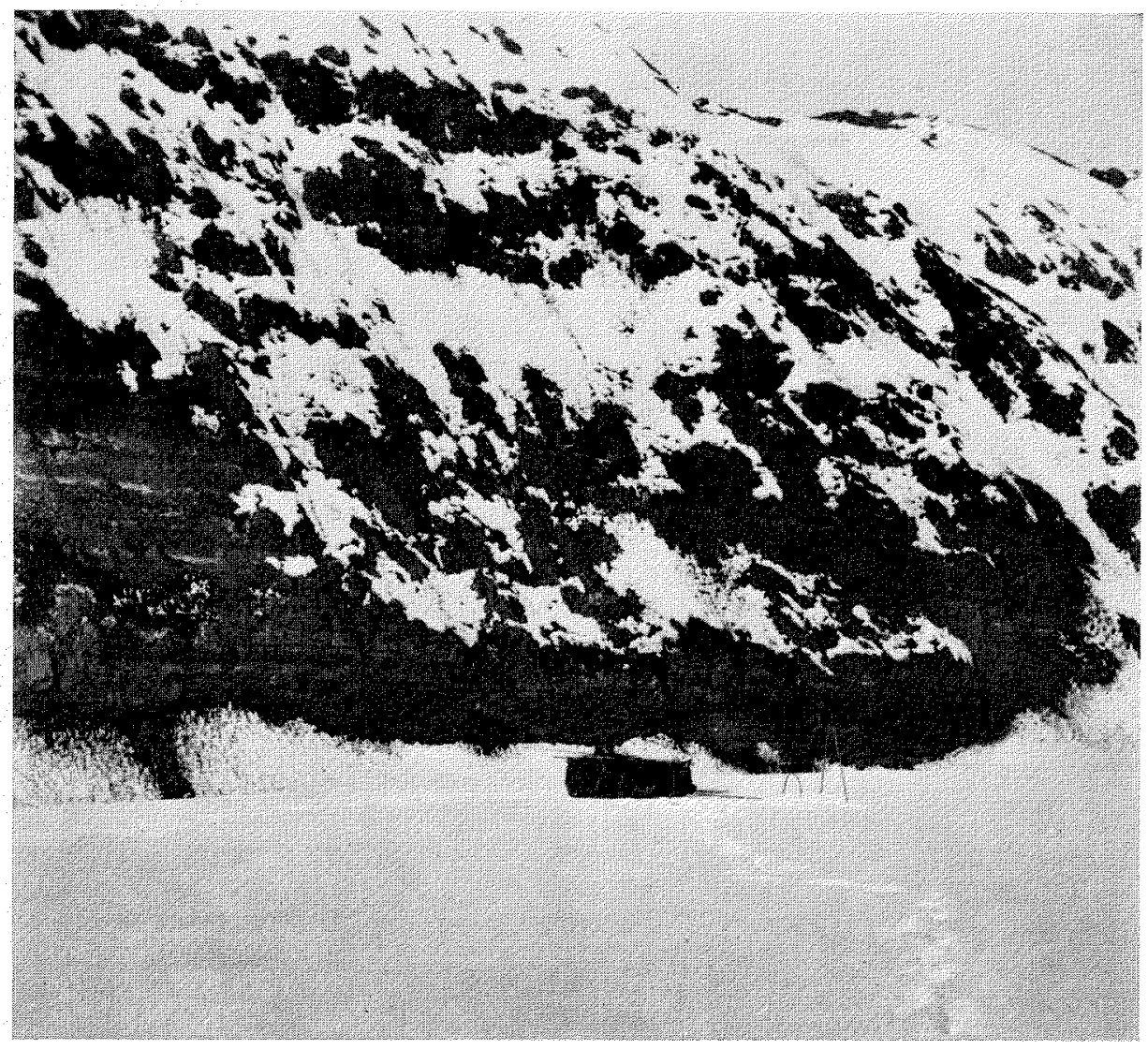

Fig. 10. Horizontal sandstone and clay with coal beds near the top of the cliff, central Fosheim Peninsula. These strata seem to have been deposited after the cessation of the Late Mesozoic-Cenozoic orogeny. April 1952.

The only Mesozoic deposit hitherto known with certainty from Ellesmere Island has been the Triassic Blaa (Blue) Mountain formation. This summer, at least one additional stratigraphic horizon was found in that region: on the plains around Slidre Fiord a sandstone bed, containing Aucella (=Buchia), is overlain by some 500 feet of soft shales, the lower part of which also contains Aucella, while higher in the shales there are (as yet unidentified) ammonites and belemnoids. The occurrence of Aucella proves the Late Jurassic-Early Cretaceous age of at least part of the sequence. Another belemnoid-carrying stratum was discovered in northeastern Fosheim Peninsula.

Parts of the skeleton of a large plesiosaurus (a marine reptile) were found in the shale formation about 2 miles from the weather station. Although the bones had been broken into innumerable fragments, it is hoped that it will be possible to reconstruct at least some of the limbs.

Our knowledge of the geological conditions in Ellesmere Island during the Middle Carboniferous, Permian, and Mesozoic times is too scattered and incomplete to permit any definite conclusions as to the extent and nature of 
the basins in which the sedimentary rocks were deposited. It is certain, though, that these sedimentary rocks have been disturbed by a gentle folding (i.e., the second folding that has affected the area), which, however, is older than the Cenozoic (or Upper (?) Cretaceous) coal beds of the region. One of these coal deposits was discovered in central Fosheim Peninsula, some 20 miles due east of the weather station (Fig. 10).

It was evident that the whole region had been covered by glacier ice during Pleistocene time, and evidence was found ${ }^{1}$ that at one time this ice cover was continuous and that it had its centre, or centres, in eastern Ellesmere Island.

When the ice receded, the sea advanced across what is now the low plain of Fosheim Peninsula, as shown by numerous finds of shells. At Slidre Fiord the highest marine beach is now about 465 feet (measured by hand level) above sea level. The thick deposits of glacial till that cover the foothills of Sawtooth Range contain numerous fragments of shells along their contact with the raised sea bed of the plain. This, besides other evidence, indicates a relatively late advance of the glaciers, which apparently have ploughed up the old sea bed.

\section{Botany}

A collection of dried mosses and flowering plants was made during my stay at Eureka weather station. These plants are now being examined at the National Museum of Canada, but it is expected that the mosses will eventually be studied by Mr. Kjeld Holmen, of the Botanical Institute, University of Copenhagen. In addition collections of seeds of the Arctic poppy were made for Professor C. A. Jørgensen, of the Royal College of Agriculture in Copenhagen, who is working on the cytology and morphology of these plants, and of seeds of various grasses and cruciferous plants for cytological examination by Mr. Kjeld Holmen.

\section{Zoology}

Berlese funnel samples of the microfauna were processed for Dr. Marie Hammer (see Arctic, Vol..2 (1949) p. 124), and a number of mosquitoes and other insects were brought back for Mr. Chr. Vibe of the Zoological Museum, University of Copenhagen.

As the area has rarely been visited a list of the wildlife observed may be of interest:

Muskox: Muskoxen are numerous on the plain of Fosheim Peninsula, and although their number is not known there appear to be as many as the land can support. It was apparent that the cows did not have calves every year. Caribou: a tuft of white caribou hair, still attached to a bit of skin, was found on the ice in central Canyon Fiord.

Arctic bare: very abundant in certain places, particularly in the foothills of the lower mountain ranges.

Lemming: not much in evidence in the spring of 1952.

${ }^{1} \mathrm{On}$ Stor Island in Eureka Sound, visited late in August. 
Polar bear: no signs of bears were seen.

Wolf: wolves and fresh wolf tracks were occasionally seen. The wolves were fearless and on a few occasions even visited my camp.

Arctic fox: a small number were seen. Like the wolves, the foxes had no fear of man.

Weasel: about June 10, a weasel (in brown summer coat) was seen in Canyon Fiord.

Seals: frequently observed on the sea ice in Canyon Fiord, Greely Fiord, and Eureka Sound.

Birds: some of the birds of the region were unknown to me, and a complete list cannot be given. It may be mentioned however, that at the end of June a black raven was seen at the mouth of Slidre Fiord. The raven seems to be very rare in the region.

\section{References}

Frebold, Hans. 1951. 'Geologie des Barentsschelfes'. Abhandl. d. deutsch. Akad.d. Wiss. Berlin, Kl. f. Matb. u. allgem. Naturwiss. (1950), No. 5, $151 \mathrm{pp}$.

Koch, Lauge. 1929. 'Stratigraphy of Greenland'. Medd. om Grøn. Vol. 73, Pt. 2, pp. $205-320$.

Troelsen, J. C. 1950a. 'Contributions to the geology of northwest Greenland, Ellesmere Island and Axel Heiberg Island'. Medd. om Gron. Vol. 149, Pt. 7, 86 pp.

Troelsen, J. C. 1950b. "Geology" in "A preliminary account of the Danish Pearyland Expedition, 1948-9" by P. C. Winther and others. Arctic, Vol. 3, pp. 6-8. 